\title{
APOPTOSIS-INDUCING POTENTIAL OF LAWSONIA ALBA LAM. LEAVES ON HEPATOCELLULAR CARCINOMA (HEP-G2) CELLS ALONG WITH ITS ANTI-OXIDANT PROPERTY
}

\author{
SOUMYASREE DUTTA ${ }^{\mathrm{a}}$, NILANJANA DEBa, ASHOK KUMAR PATTNAIK ${ }^{\mathrm{b}}$, SHILA ELIZABETH BESRA ${ }^{\mathrm{a} *}$ \\ aCancer Biology and Inflammatory Disorder Division, CSIR-Indian Institute of Chemical Biology, 4, Raja S. C. Mullick Road, Kolkata \\ 700032, West Bengal, India, bDepartment of Pharmaceutical Science and Technology, Birla Institute of Technology Mesra, Ranchi, 835215, \\ Jharkhand, India \\ Email: shilabesra@iicb.res.in
}

Received: 13 May 2016 Revised and Accepted: 22 Jul 2016

\begin{abstract}
Objective: The current study investigated the anti-cancer potential of methanolic and ethyl acetate fraction of Lawsonia alba L. (Lythraceae) leaves extract on Hep-G2 and RAW 264.7 cells along with in vitro anti-oxidant property of the ethyl acetate fraction.

Methods: The cytotoxic activity of methanolic extract and its fractions had been studied by MTT assay on Hep-G2 and RAW 264.7 cells. Morphological study of Hep-G2 cells was performed by light, fluorescence and confocal microscope. 1\% agarose gel electrophoresis, detection of apoptosis and cell cycle arrest by flow cytometric analysis had been performed to determine the proportion and stages of cellular apoptosis of HepG2 cells. In vitro anti-oxidant study of various fractions of MLA were performed by DPPH and Hydroxyl radical scavenging assay.

Results: Cytotoxicity study of MLA and ELA had been confirmed by MTT assay and the IC ${ }_{50}$ value were calculated to be $75.85 \mu \mathrm{g} / \mathrm{ml}$ and $32.81 \mu \mathrm{g} / \mathrm{ml}$ on Hep-G2 cell line respectively. Morphological study showed the arrays of nuclear changes including chromatin condensation and apoptotic body formation indicating that treatment with ELA, causes apoptotic changes in the hepatoma cells compared to the untreated control. Agarose gel electrophoresis study showed fragmented DNA in the form of a ladder. Flow cytometric analysis showed an appreciable number of cells in early apoptosis stage. The cells were arrested, mostly in G0/G1 phase of the cell cycle. Antioxidant property of ELA fraction was confirmed by free radical scavenging activity.
\end{abstract}

Conclusion: Ethyl acetate fraction of Lawsonia alba L. leaves possess potent apoptotic activity against Hep-G2 cell line along with notable antioxidant activity.

Keywords: Lawsonia alba, Leaves, Hepatocellular carcinoma, Apoptosis, Antioxidant

(C) 2016 The Authors. Published by Innovare Academic Sciences Pvt Ltd. This is an open access article under the CC BY license (http://creativecommons. org/licenses/by/4. 0/) DOI: http://dx.doi.org/10.22159/ijpps.2016.v8i9.12815

\section{INTRODUCTION}

Cancer leads to cause of mortality in most of the countries of this world. Characteristically cancer is the cell proliferation independent of growth factor regulation with apoptosis resistance and angiogenesis, leading to the disruption of homeostatic condition therapy to tumorigenesis. Several types of cancers are there affecting different organs, including brain, liver, lungs, kidney, breast, bones and ovaries [1]. The most common type of liver cancer, Hepatocellular carcinoma (HCC) or malignant hepatoma, is phenotypically (morphology and microscopy) and genetically heterogeneous tumors reflecting the etiological factors implicated in HCC development [2]. Cancer produces an ambience of oxidative stress. Antioxidants are known to reduce this stress by direct scavenging of ROS, up regulation of DNA repair system [3]. Lawsonia alba Lam. plant, a member of 'Lythraceae' family is used in several ailments, including antimicrobial [4], analgesic, anti-fertility activity, anti-sickling activity, anti-diabetic [5], anti-inflammatory and hepato-protective effects [6] with anti-oxidant property [3]. The phytochemistry of Lawsonia alba plant was largely studied and revealed interesting facts. In 1973, four fractions with antibacterial activity were isolated by thin-layer chromatography of the ethanolic extract of Lawsonia alba Lam leaves, among them three compounds are gallic acid [149-91-7], lawsone [83-72-7] and 1,4naphthoquinone [130-15-4] [7]. From leaves extracts of Lawsonia alba flavonoids like apigenin-7-O-glucoside, apigenin-4'-O-glucoside, luteolin-7-O-glucoside, and luteolin-3'-O-glucoside were isolated. Besides these two pentacyclic triterpenoids named as lawsonic acid I [3 $\beta$-E-ferulyloxy-lup-20(29)-en-28-oic acid] and Lawsonin II [3 $\beta$-Eferulyloxy-urs-11-en-13 $\beta$-ol] have been also isolated from the aerial parts of Lawsonia alba [8]. Amino derivatives of lawsone and lapachol were identified, showing the cytotoxicity against Ehrlich carcinoma and human K562 (leukemia cells). Similarly, when henna
$(0.5 \mathrm{mg} / \mathrm{ml})$ and lawsone $(0.015 \mathrm{mg} / \mathrm{ml})$ were applied topically on the back skin in the UV-B initiated/TPA promoted and per-oxynitrite initiated/TPA promoted mouse skin carcinogenesis models, antitumor activities were observed [9]. Though, ethyl acetate fraction of Lawsonia alba has a wide range of cytotoxic activity [10] but, no work on hepatocellular carcinoma has been reported so far. The present investigation is an approach to study the apoptosis inducing activity of active fraction from Lawsonia alba leaves against Hepatocellular carcinoma (Hep-G2) along with the anti-oxidant property.

\section{MATERIALS AND METHODS}

\section{Chemicals and reagents}

DMEM, RPMI (Gibco), fetal bovine serum(FBS), trypsin (Gibco, USA), sorafenib tosylate (Brand name: Nexavar, Bayer and Onyx Pharmaceuticals), penicillin-streptomycin (Biowest, Germany), gentamycin (Nicholas, India), HEPES, L-glutamine, MTT, acridine orange, ethidium bromide, agarose (Puregene), proteinase k (SRL), Annexin-V FITC (apoptosis kit), RNAse, propidium iodide (Sigma), DMSO (dimethylsulphoxide), petroleum ether, chloroform, methanol, ethyl acetate, n-butanol, DPPH, hydrogen peroxide, ascorbic acid, ferrous sulphate, salicylic acid (Merck). All other chemicals were of analytical grade were procured locally.

\section{Cell culture}

Hep-G2 (Hepatocellular carcinoma cell line) and RAW264.7 cells (Macrophage cell line) were obtained from the National Facility for Animal Tissue and Cell Culture, Pune, India. The Hep-G2 cells were cultured and routinely maintained in DMEM and RAW264.7 cells were cultured and maintained in RPMI 1640 medium. Both the medium was supplemented with $10 \%$ heat inactivated fetal bovine serum (FBS), penicillin (100 units $/ \mathrm{ml})$, streptomycin $(100 \mu \mathrm{g} / \mathrm{ml})$, 
gentamycin $(100 \mu \mathrm{g} / \mathrm{ml})$ and were incubated at $37^{\circ} \mathrm{C}$ in a humidified atmosphere containing $5 \% \mathrm{CO}_{2}$ inside a $\mathrm{CO}_{2}$ incubator. Both Hep-G2 and Raw 264.7 cells are adherent in nature. During sub culturing of cells the adherent property can be diminished by adding $1 \mathrm{x}$ trypsin solution in the cell [11].

\section{Collection and identification of plant specimen}

Lawsonia alba Lam leaves were collected from Ranchi, Jharkhand and identified by Dr. V. P. Prasad, Scientist-D, Central National Herbarium, Botanical Survey of India, Ministry of Environment and Forests, and Government of India at Howrah, West Bengal. The specimen authentication no. is CNH/Tech. П/2014/75/158.

\section{Preliminary phytochemical screening}

The phytochemical constituents present in Lawsonia alba Lam. leaves were qualitatively identified in the methanol extracts and have been reported earlier. Methanolic leaves extract of Lawsonia alba Lam. showed the presence of phytochemical constituents like flavonoids (Shinoda and zinc chloride test), tannin (ferric chloride test), coumarins, steroids (Liebermann Burchard and Salkowski test) carbohydrate (Molisch's test), napthoquinones (Juglone test and Dam-Kerrer test) etc. than other extracts as selected by phytochemical screening [12]. The methanolic extracts of L. inermis showed considerable antioxidant potential in all the analytical studies. The results of the DPPH, ABTS and FRAP assays were in congruity with those previously reported [13]. The administration of methanolic extract of Lawsonia alba Lam. leaves is safe and has no adverse effect on growth related and biochemical parameters indicating its safety.

\section{Extraction and fractionation of Lawsonia alba Lam. leaves extract}

The leaves of Lawsonia alba were harvested and air dried, then ground into powder form at room temperature $\left(24-27^{\circ} \mathrm{C}\right)$. The powder $(1 \mathrm{~kg})$ was defatted by petroleum ether and soaked in chloroform for $3 \mathrm{~d}$ to free chlorophyll and then soaked in $6000 \mathrm{ml}$ of methanol for $7 \mathrm{~d}$ at ambient temperature. The methanolic extract was filtered, followed by solvent evaporation under vacuum at 40$45^{\circ} \mathrm{C}$. The yield was obtained to be 300 gm of crude extract (30\%). The sticky methanolic extract obtained finally was kept in a container, sealed with parafilm and stored at $4{ }^{\circ} \mathrm{C}$ in an airtight container. The methanolic extract of L. alba Lam. leaves was designated as MLA. 10 gm MLA extract was subjected to further fractionation by separating funnel method using different solvents $(200 \mathrm{ml})$ like ethyl acetate (ELA), n-butanol (BLA) and water (WLA) [14]. Removal of the solvents in a rotary evaporator (BÜCHI rotavapor R-200, BÜCHI Labortechnik AG, Switzerland) yielded 750 $\mathrm{mg}$ of ELA, $125 \mathrm{mg}$ of BLA and $95 \mathrm{mg}$ of WLA fraction.

\section{Estimation of chemical composition of Lawsonia alba Lam. leaves}

Total flavonoid content by aluminium chloride colorimetric method

Quercetin (Q) was used to prepare the calibration curve. $10 \mathrm{mg}$ of quercetin was dissolved in $80 \%$ ethanol, diluted to $12.5,25,50$, $100,120 \mu \mathrm{g} / \mathrm{ml}$. $1.5 \mathrm{ml}$ of $95 \%$ ethanol, $0.1 \mathrm{ml}$ of $10 \%$ aluminium chloride, $0.1 \mathrm{ml}$ of $1 \mathrm{M}$ potassium acetate and $2.8 \mathrm{ml}$ of distilled water were added separately to the each $0.5 \mathrm{ml}$ diluted standard solutions of varying concentrations. The absorbance was taken at $415 \mathrm{~nm}$ using UV-Visible spectrophotometer (UV-2700, SHIMADZU) after incubating at room temperature for $30 \mathrm{~min}$. The amount of $10 \%$ aluminium chloride was substituted by the same amount of distilled water in the blank. The methodology was repeated with each fraction of different concentrations for determination of total flavonoid content. The result was expressed as milligrams of quercetin equivalents (QE) per gm of dry extract [4].

\section{Total phenolic content by the folin-ciocalteu method}

$0.5 \mathrm{ml}$ of each fraction having the concentrations of 2,4,6,8 and $10 \mu \mathrm{g} / \mathrm{ml}$ was added to $1.5 \mathrm{ml}$ (1:10 v/v diluted with distilled water) Folin Ciocalteau's reagent and allowed to stand at $22^{\circ} \mathrm{C}$ for $5 \mathrm{~min}$. Then $2 \mathrm{ml}$ of sodium carbonate $\left(\mathrm{Na}_{2} \mathrm{CO}_{3}, 7.5 \% \mathrm{w} / \mathrm{v}\right)$ was added to each fraction of different concentrations. The mixtures were kept in dark and allowed to stand for another $90 \mathrm{~min}$. The absorbance of the blue colored solution was measured at $725 \mathrm{~nm}$ using UV-Visible spectrophotometer (UV-2700, SHIMADZU). Gallic acid (GA) was used to make the standard curve using the same process mentioned above and the total phenolic contents in each fraction were expressed as milligrams of gallic acid equivalent (GAE) per gram of dry extract [4].

\section{In vitro antioxidant study \\ DPPH radical scavenging activity}

A stock solution of $0.1 \mathrm{mM}$ DPPH in methanol was prepared by adding $150 \mu \mathrm{l}$ of DPPH solution to $3 \mathrm{ml}$ methanol. $50 \mu \mathrm{l}$ of each of the various concentrations of ELA, BLA, and WLA extracts was taken and volume made up to $150 \mu \mathrm{l}$ with methanol. It was further diluted with upto $3 \mathrm{ml}$ methanol and $150 \mu \mathrm{l}$ DPPH solution was added. Absorbance was taken after 15 min using UV-Visible spectrophotometer (UV-2700, SHIMADZU) at $517 \mathrm{~nm}$ using methanol as blank and ascorbic acid (AA) was used as positive control [15].

\section{Hydroxyl radical scavenging assay}

To $2 \mathrm{ml}$ of various concentrations of all the fractions, $600 \mu \mathrm{l}$ of $8 \mathrm{mM}$ $\mathrm{FeSO}_{4}$ solution and $500 \mu \mathrm{l}$ of hydrogen peroxide of $20 \mathrm{mM}$ was added. To initiate the reaction $3 \mathrm{mM}$ salicylic acid solution was added. The mixture was allowed to stand for $30 \mathrm{~min}$ at $37^{\circ} \mathrm{C} .900 \mu \mathrm{l}$ of distilled water was then added to the mixture followed by centrifugation at $10,000 \mathrm{rpm}$ for $10 \mathrm{~min}$. The supernatant was collected and absorbance taken using UV-Visible spectrophotometer (UV-2700, SHIMADZU) at $510 \mathrm{~nm}$. Ascorbic acid (AA) served as positive control [3].

For both methods, formulas to calculate percentage inhibition,

$$
\begin{gathered}
\text { Scavenging activity }(\%)=[(\text { Control abs. }- \text { Test abs }) / \text { Control abs }] \\
\text { x100 }
\end{gathered}
$$

\section{In vitro cell viability study}

\section{Cytotoxicity study by MTT assay}

To analyze the cytotoxicity study, $100 \mu$ cell suspension $\left(1 \times 10^{5}\right)$ of Hep-G2 and RAW264.7 cells respectively were seeded separately in 96 well tissue culture plates. They were separately treated with 1 $\mathrm{mg} / \mathrm{ml}$ MLA stock solution and its various fractions at the doses of $25 \mu \mathrm{g}, 50 \mu \mathrm{g}, 100 \mu \mathrm{g}$ for 24,48 and $72 \mathrm{~h}$. RAW264.7 cells were treated with same concentrations of ELA for $24 \mathrm{~h}$. Both plates were incubated at $37{ }^{\circ} \mathrm{C}$ in a humidified atmosphere containing $5 \% \mathrm{CO}_{2}$ in the air. Untreated Hep-G2 cells (control) and Sorafenib tosylate (Standard) treated cells were treated with $\mathrm{IC}_{50}$ dose. The cytotoxicity study was performed by MTT assay with slight modifications. $100 \mu \mathrm{l}$ of the supernatant was removed, $20 \mu \mathrm{l}$ of MTT [3-(4, 5-dimethylthiozol-2-yl) 2, 5-dipheyltetrazolium bromide] (5 $\mathrm{mg} / \mathrm{ml}$ ) was added to each well and $100 \mu \mathrm{l}$ of fresh media was then added to each well. The plates were again incubated for 3-4 $\mathrm{h}$ at 37 ${ }^{\circ} \mathrm{C}$. To dissolve the insoluble purple colored product $100 \mu \mathrm{L}$ DMSO (solubilizing solution) was added. The absorbance was observed at $570 \mathrm{~nm}$ for Hep-G2 and at $492 \mathrm{~nm}$ for RAW264.7 cells respectively by micro plate manager (Reader type Model 680 XR Bio-Rad laboratories lnc.) and the \% inhibition was determined using the relation as under state [16].

\section{In vitro morphological study}

\section{Light microscopic study}

$1 \times 10^{6}$ cells (HepG2) were treated with ELA (IC ${ }_{50}$ dose $32.81 \mu \mathrm{g}$ ) in a sterile petri-plate and incubated for $24 \mathrm{~h}$ at the conditions mentioned above. The cells were then washed twice with PBS and observed under a light microscope (Lecia Microscope) at a magnification of $40 \mathrm{X}$ [11].

\section{Fluorescence microscopic study}

Hep-G2 cells $\left(1 \times 10^{6}\right)$ were treated with ELA with $\mathrm{IC}_{50}$ concentration $(32.81 \mu \mathrm{g})$ in a sterile cover slip and incubated for $24 \mathrm{~h}$ at the specific 
conditions mentioned above. After washing with cold PBS, the cells were treated with $10 \mu \mathrm{l}$ of staining solution containing acridine orange and ethidium bromide in 1:1 ratio and immediately observed under a fluorescence microscope (Lecia Fluorescence Microscope) at a magnification of 60X, excitation range-blue filter BP450-490, dichromatic mirror-510 and suppression filter-LP515 [11].

\section{Confocal microscopic study}

Hep-G2 cells $\left(1 \times 10^{6}\right)$ were treated with $\mathrm{IC}_{50}$ dose of ELA $(32.81 \mu \mathrm{g})$ for $24 \mathrm{~h}$. After $24 \mathrm{~h}$ untreated control cells and ELA treated cells were harvested and washed with ice cold PBS. The cells were then stained with $10 \mu \mathrm{g} / \mathrm{ml}$ of propidium iodide for $5 \mathrm{~min}$. The cells were mounted on slides to observe the differences in nuclear morphology between untreated and ELA treated Hep-G2 cells under a confocal laser scanning microscope (Leica TCS-SP2 system, Leica Microsystem, Heidelberg, Germany) installed with an inverted microscope [Leica DM-7RB] [11]. Images for propidium iodide was acquired from argon/krypton laser and UV laser line using $590 \mathrm{~nm}$ long pass filter for propidium iodide for images.

\section{In vitro apoptosis study}

\section{DNA fragmentation study by agarose gel electrophoresis}

Fragmentation of chromatin to units of single or multiple nucleosomes that form the nucleosomal DNA ladder in agarose gel is an established hallmark of programmed cell death or apoptosis. Hepatocellular carcinoma (Hep-G2) cells $\left(1 \times 10^{6}\right)$ were treated with IC $50(24 \mathrm{~h})$ doses of each cell line with ELA and standard anti-cancer drug sorafenib tosylate $(100 \mu \mathrm{g} / \mathrm{ml})$ for $24 \mathrm{~h}$. The cells were harvested and washed twice with PBS. The cells were re-suspended in $500 \mu \mathrm{l}$ of lysis buffer ( $50 \mathrm{mM}$ Tris-HCl, $\mathrm{pH}-8.0,10 \mathrm{mM}$ EDTA, $0.5 \%$ SDS), $10 \mu \mathrm{g}$ of proteinase-k was added and lysis was initiated by incubation at $50{ }^{\circ} \mathrm{C}$ for $1 \mathrm{hr}$ at $37{ }^{\circ} \mathrm{C}$ overnight respectively. After that, DNA extraction was done, following the general phenolchloroform extraction procedure. To detect the DNA fragments, the isolated DNA samples were mixed with loading dye and were subjected to $1 \%$ agarose gel electrophoresis for overnight at $20 \mathrm{~V}$ using ethidium-bromide. DNA fragmentation was observed in UV transilluminator (GENEI, Bangalore Genei Pvt. Ltd.) [17].

\section{Detection of apoptosis by flow cytometry}

Flow cytometric analysis was done by performing dot plot assay to investigate the type of cell death induced by ELA [18]. The Hep-G2 cells $\left(1 \mathrm{x} 10^{6}\right)$ were treated individually with IC ${ }_{50}$ dose of ELA for 18 h. Next, the cells were centrifuged at $2000 \mathrm{rpm}$ for $8 \mathrm{~min}$ at $4{ }^{\circ} \mathrm{C}$ and were pellet down. The cell pellets were washed with Annexin-FITC binding buffer provided in apoptosis kit (Sigma). Again, after centrifuging at $2000 \mathrm{RPM}$ at $4{ }^{\circ} \mathrm{C}$, the cell pellets were dissolved in Annexin-FITC binding buffer containing Annexin-FITC and propidium iodide. After 15 min incubation in the dark at room temperature, flow Cytometric analysis was done. All data were taken by Becton-Dickinson FACS LSR Fortessa 4 laser Cytometer. Reading of flow cytometry was taken using $488 \mathrm{~nm}$ excitation and band pass filters of 530/30 nm (for FITC detection) and 585/42 nm (for PI detection). Live statistics were used to align the $X$ and $Y$ mean values of the Annexin-V FITC or PI stained quadrant populations by compensation. Data analysis was performed by BD FACS Diva software program [11].

\section{Study of cell cycle arrest by flow cytometry}

Hep-G2 $\left(1 \times 10^{6}\right)$ cells were treated with ELA (IC ${ }_{50}$ dose) for $18 \mathrm{~h}$ to assay the stage of cell cycle arrest in a flow cytometry [19]. Cells were washed with PBS, fixed with cold methanol. Then, they were resuspended in cold PBS and kept at $4{ }^{\circ} \mathrm{C}$ for $90 \mathrm{~min}$. Cells were pelleted down, dissolved in cold PBS, treated with RNase for $30 \mathrm{~min}$ at $37{ }^{\circ} \mathrm{C}$ and stained with propidium iodide and kept in dark for 15 min. Cell cycle phase distribution of nuclear DNA was determined on FACS (Becton Dickinson FACS Fortessa 4 laser Cytometer), fluorescence detector equipped with $488 \mathrm{~nm}$ argon laser light source and $623 \mathrm{~nm}$ band pass filter (linear scale) with the help of BD FACS Diva software (Becton Dickinson).

\section{Statistical analysis}

The percentage cell inhibition was calculated by the following formula,

$$
\% \text { Cell inhibition }=100 \times[(\mathrm{OD} \text { of control-OD of treated }) / \mathrm{OD} \text { of }
$$
control]

$\mathrm{OD}=$ Optical density. The percentage cell viability was calculated by the formula,

Viable cells $(\%)=($ Total number of viable cells per $\mathrm{ml} /$ Total number of cells per $\mathrm{ml}) \times 100$.

The data were analyzed statistically using one way ANOVA followed by Dunnet's t-test. The data were expressed as mean \pm SEM. "P" value less than 0.05 implied significance. Values were expressed as mean ${ }^{*} \mathrm{P}<0.05,{ }^{* *} \mathrm{P}<0.01$ when compared to control.

\section{RESULTS}

Estimation of chemical constituents of Lawsonia alba Lam. leaves

Ethyl acetate fraction (ELA) of Lawsonia alba leaves showed significant presence of flavonoids and polyphenols, among the three fractions of methanolic extract, with respect to the standards respectively. The total flavonoid content of ELA fraction was $76.82 \pm 2.9$ $\mathrm{mg} / \mathrm{gm}$ and total poly-phenols content was $107.88 \pm 4.1 \mathrm{mg} / \mathrm{gm}$.

Table 1: Chemical yield in various fractions of $L$. alba methanolic leaves extract

\begin{tabular}{lll}
\hline Type of fractions & Total flavonoid (Eq. Quercetin in mg/gm dry) & Total polyphenols (Eq. Gallic acid in mg/gm dry) \\
\hline Ethyl acetate & $76.82 \pm 2.9$ & $107.88 \pm 4.1$ \\
N-butanol & $17.1 \pm 0.7$ & $71.8 \pm 1.9$ \\
Aqueous & $51.4 \pm 2.1$ & $96.8 \pm 3.5$ \\
\hline
\end{tabular}

Data are mean $\pm S E M$ of triplicate determination

\section{In vitro antioxidant study}

Among the three fractions of MLA extract, the ethyl acetate fraction (ELA) demonstrated potent free radical scavenging activity than
BLA, and WLA fraction as confirmed by DPPH and hydroxyl radical scavenging assay. Ascorbic acid was used as standard drug. The percentage scavenging activity of ELA fraction increased consistently with increasing concentrations.

Table 2: Antioxidant study of various fractions of $L$. alba methanolic leaves extract

\begin{tabular}{lll}
\hline Type of extract & $\mathbf{I C}_{\mathbf{5 0}}(\boldsymbol{\mu \mathbf { g }} / \mathbf{m l})$ & \\
\cline { 2 - 3 } & $\mathbf{D P P H}$ assay & Hydroxyl radical scavenging assay \\
\hline Ascorbic acid & $15.76 \pm 0.2$ & $92.90 \pm 0.6$ \\
Ethyl acetate & $16.93 \pm 0.5$ & $99.08 \pm 0.9$ \\
Aqueous & $19.78 \pm 0.8$ & $102.08 \pm 1.5$ \\
N-butanol & $20.0 \pm 0.95$ & $104.07 \pm 2.4$ \\
\hline
\end{tabular}

Data are mean \pm SEM of triplicate determination 


\section{In-vitro cell viability study}

Cytotoxicity study on Hep-G2 and RAW264.7 cell line by MTT assay

In the anti-proliferative study by MTT assay there was significant reduction in a time and concentration dependent manner in the 0 . D. values compared to that of the untreated control cells upon treating the cells with MLA and ELA at the concentration of $25 \mu \mathrm{g}, 50 \mu \mathrm{g}$ and $100 \mu \mathrm{g}$ for 24, 48 and $72 \mathrm{~h}$ in Hep-G2 cell line (fig. 1 and fig. 2). But, no significant cytotoxic effect was observed in Hep-G2 cell line treated with BLA and WLA with the same concentration for $24 \mathrm{~h}$.

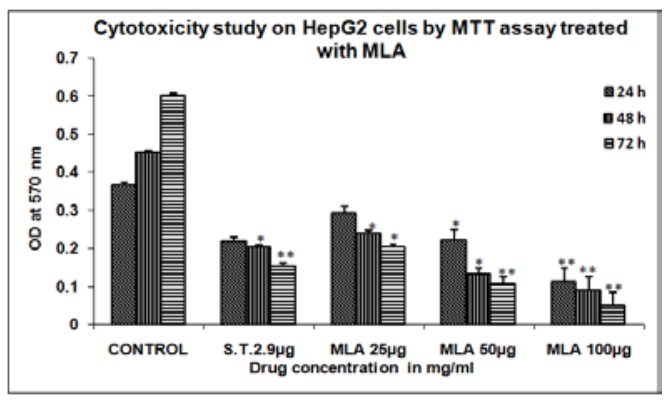

Fig. 1: The histogram showed significant reduction in Hep-G2 cells after the treatment with methanolic leaves extract (MLA) of $L$. alba compared to control in a concentration and timedependent manner

Data are mean \pm SEM of triplicate determination. *,** denote a significant decrease in $\mathrm{O}$. D. at $570 \mathrm{~nm}$ from control values $\mathrm{P}<0.05$, $\mathrm{P}<0.01$ respectively. $\mathrm{S} . \mathrm{T}=$ Sorafenib tosylate (standard)

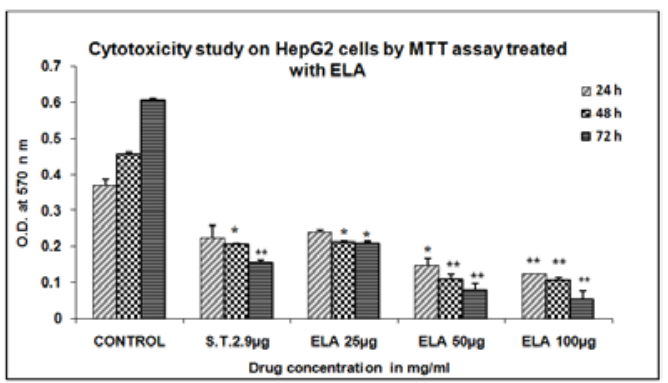

Fig. 2: The histogram showed significant reduction in Hep-G2 cells after the treatment with ethyl acetate (ELA) fraction of $L$. alba leaves compared to control in a concentration and timedependent manner

Data are mean \pm SEM of triplicate determination. ${ }^{*}, * *$ denote a significant decrease in 0 . D. at $570 \mathrm{~nm}$ from control values $\mathrm{P}<0.05$, $\mathrm{P}<0.01$ respectively. $\mathrm{S}$. $\mathrm{T}=$ Sorafenib tosylate (standard)

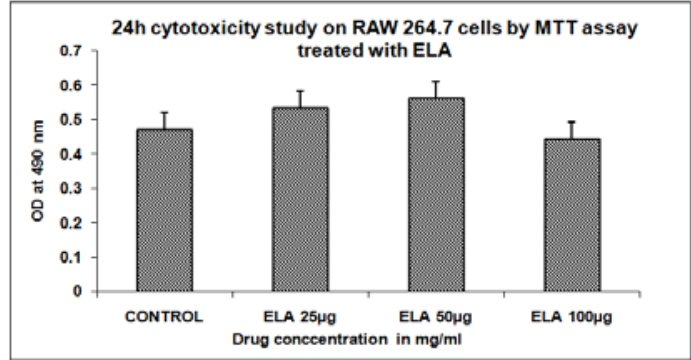

Fig. 3: The histogram showed an insignificant toxic effect on the RAW264.7 cells treated with ethyl acetate (ELA) fraction of $L$. alba leaves for $24 \mathrm{~h}$ as observed by the MTT assay

Data are mean \pm SEM of triplicate determination

Treatment with ELA for $24 \mathrm{~h}$ did not show any cytotoxic activity on the RAW264.7 murine macrophage cells, whereas consecutive doses up to $50 \mu \mathrm{g}$ showed an increase in the growth of RAW264.7 cells at $492 \mathrm{~nm} \mathrm{O.} \mathrm{D.} \mathrm{as} \mathrm{observed} \mathrm{by} \mathrm{MTT} \mathrm{assay} \mathrm{(fig.} \mathrm{3).} \mathrm{It} \mathrm{can} \mathrm{be} \mathrm{inferred}$ that ELA fractions do not confer any toxicity to healthy normal cells. The IC 50 value of MLA and ELA for HepG-2 cell line was found to be $75.85 \mu \mathrm{g} / \mathrm{ml}$ and $32.81 \mu \mathrm{g} / \mathrm{ml}$ respectively.

\section{In vitro morphological study}

\section{Light microscopic study}

Light microscopic images of Hep-G2 cells treated with ELA (IC 50 dose) revealed the presence of fragmented nuclei as compared to the untreated control cells with intact nuclei (fig. 4).

\section{Fluorescence microscopic study}

Furthermore, the effect of ELA was observed to produce cell death in Hep-G2 cell lines by inducing apoptosis. Fluorescence microscopic images showed untreated control cells, having intact nuclei stained with only acridine orange gives a green fluorescence (fig. 4). Whereas, treated hepatoma cells with condensed chromatin fragmented nuclei were stained with both acridine orange and ethidium bromide. Arrays of nuclear changes, including chromatin condensation and apoptotic body formation indicated that treatment with ELA caused the apoptotic changes in the hepatoma cells.

Cellular and nuclear morphological studies by confocal microscopy

ELA induced apoptotic changes in Hep-G2 cells after $24 \mathrm{~h}$ of treatment showed chromatin disintegration and formation of apoptotic bodies, whereas the untreated control cells showed intact nuclei (fig. 6).

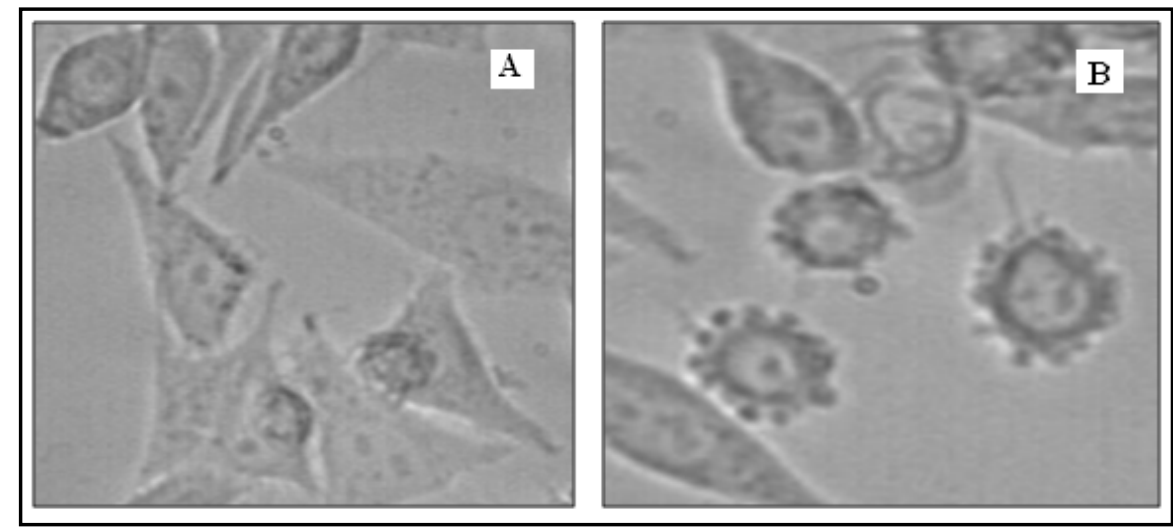

Fig. 4: Light microscopic images of Hep-G2 cells showed (A) untreated control cells with intact nuclei, (B) ethyl acetate (ELA) fraction of $L$. alba leaves treated cells with fragmented nuclei showing signs of apoptosis 


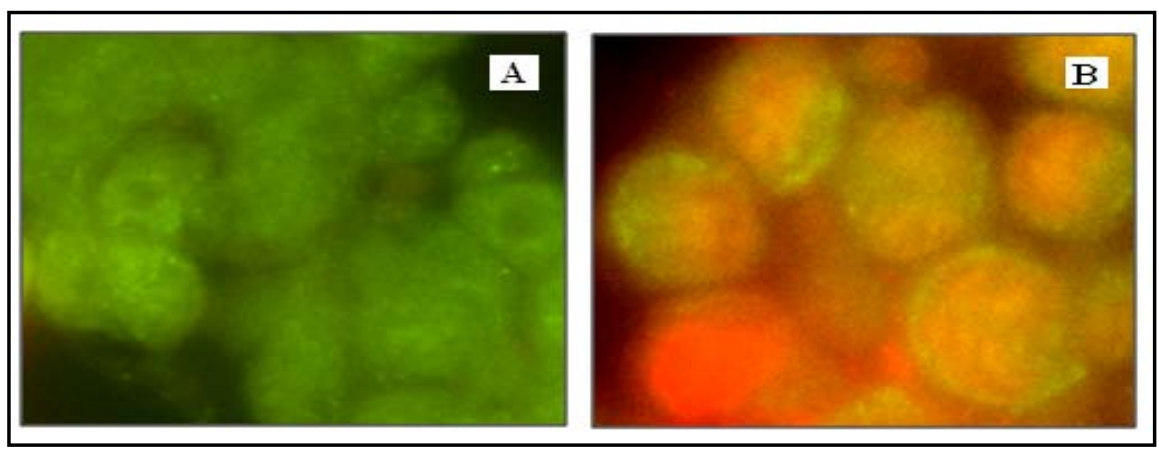

Fig. 5: Fluorescence microscopic images showed untreated control (A) cells were with intact nuclei and gave bright green fluorescence whereas ethyl acetate (ELA) fraction of L.alba leaves treated (B) Hep-G2 cells were intense orange-red fluorescence showing signs of apoptosis

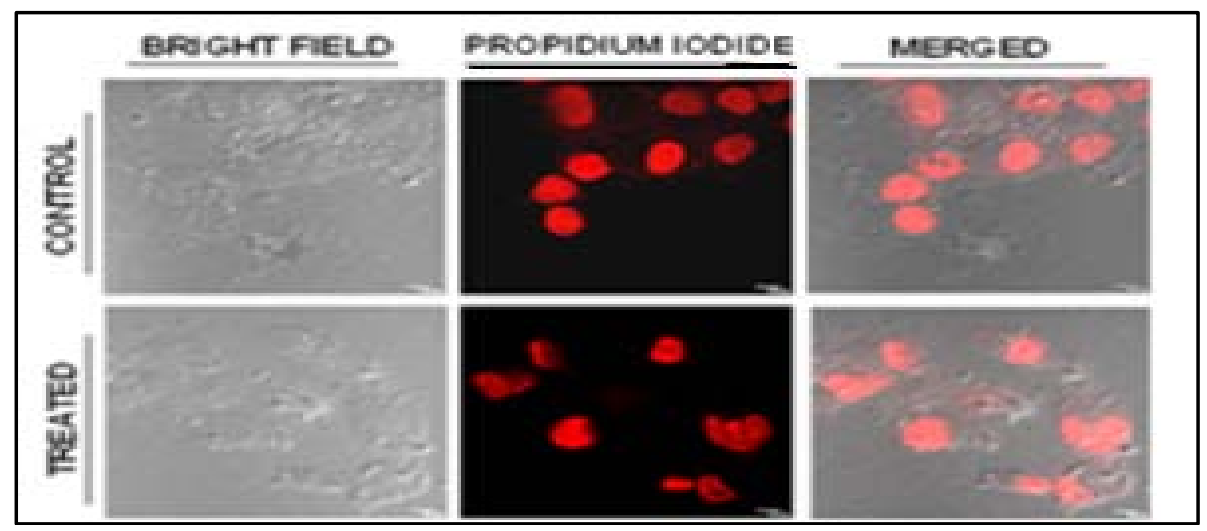

Fig. 6: Confocal microscopic images of Hep-G2 cells showed apoptotic changes like nuclear disintegration and formation of apoptotic bodies for ethyl acetate (ELA) fraction of $L$. alba leaves treated cells stained with propidium iodide whereas untreated control cells showed intact nuclei

\section{In vitro apoptosis study}

Detection of apoptosis by DNA fragmentation and agarose gel electrophoresis

The gel pattern of DNA samples isolated from untreated control Hep-G2 cells showed an intact DNA band whereas gel pattern of the DNA samples, isolated from ELA (IC ${ }_{50}$ dose) treated Hep-G2 cells showed degraded DNA bands in the form of ladders. By these observations, it can be confirmed that the treatment with ELA caused apoptosis in hepatocellular carcinoma cell (fig. 7).

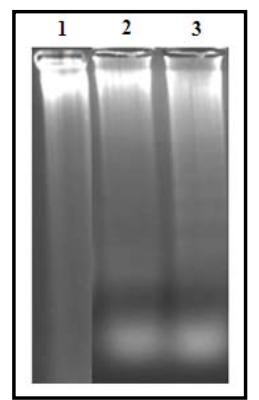

Fig. 7: Agarose gel electrophoresis study for the detection of apoptosis presented control lane1, sorafenib tosylate (STD) lane 2 and ethyl acetate (ELA) fraction of $L$. alba leaves treated lane 3 of HepG-2 cells. The gel pattern of DNA samples isolated from Hep-G2 cells treated with ELA showed distinct DNA ladder formation like standard indicating the process of apoptosis

\section{Detection of apoptosis by flow cytometric analysis}

For the detection of apoptosis by flow cytometric analysis, double labeling technique, using Annexin V FITC and propidium iodide, was utilized. Lower left (LL) quadrant (Annexin V-/PI-) depicted the population of live cells, lower right quadrant (LR) (Annexin V+/PI-) was regarded as the cell population at early apoptotic stage, upper right (UR) quadrant (Annexin $\mathrm{V}+\mathrm{PI}+$ ) represented the cell population at late apoptotic stage and extreme upper right (UR) and upper left (UL) quadrant (Annexin V-/PI+) was considered as necrotic cell population. Flow cytometric data analysis revealed that, after $18 \mathrm{~h}$ treatment $1.9 \%$ control and $23.2 \%$ ELA (IC 50 dose) treated Hep-G2 cells were in the LR quadrant indicating early apoptotic phase. (fig. 8).

\section{Study of cell cycle arrest by flow cytometric analysis}

Flow cytometric analysis showed that after $18 \mathrm{~h}$ treatment of Hep-G2 with ELA at $\mathrm{IC}_{50}$ dose, G0/G1 peak was changed. DNA content increased in treated HepG2 cells (77.4\%) than the control $(61.3 \%)$ for both in G0/G1 phase. These results confirmed that, the drug treatment arrested the cell cycle of the cells mostly at G0/G1 phase (fig. 9).
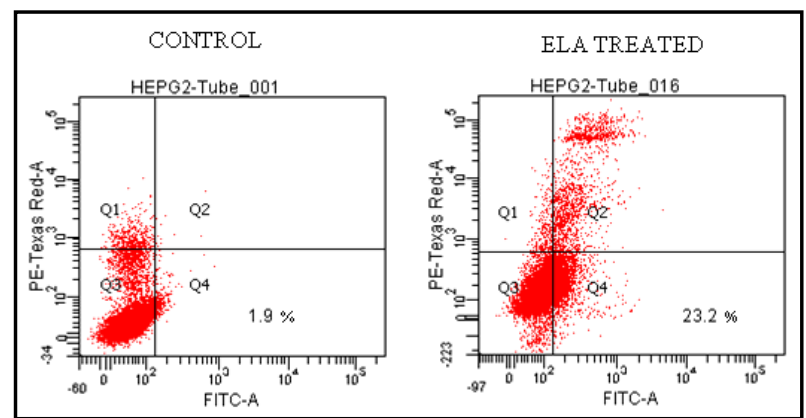

Fig. 8: Detection of apoptosis by flow cytometric analysis of

Hep-G2 cells in both control and ethyl acetate (ELA at IC 50 doses) fraction of $L$. alba leaves treated cells respectively, after

$18 \mathrm{~h}$. Staining was done with Annexin V FITC and propidium iodide. Dual parameter dot plot of FITC-fluorescence ( $x$-axis) vs. PI-fluorescence ( $y$-axis) showed logarithmic intensity. 


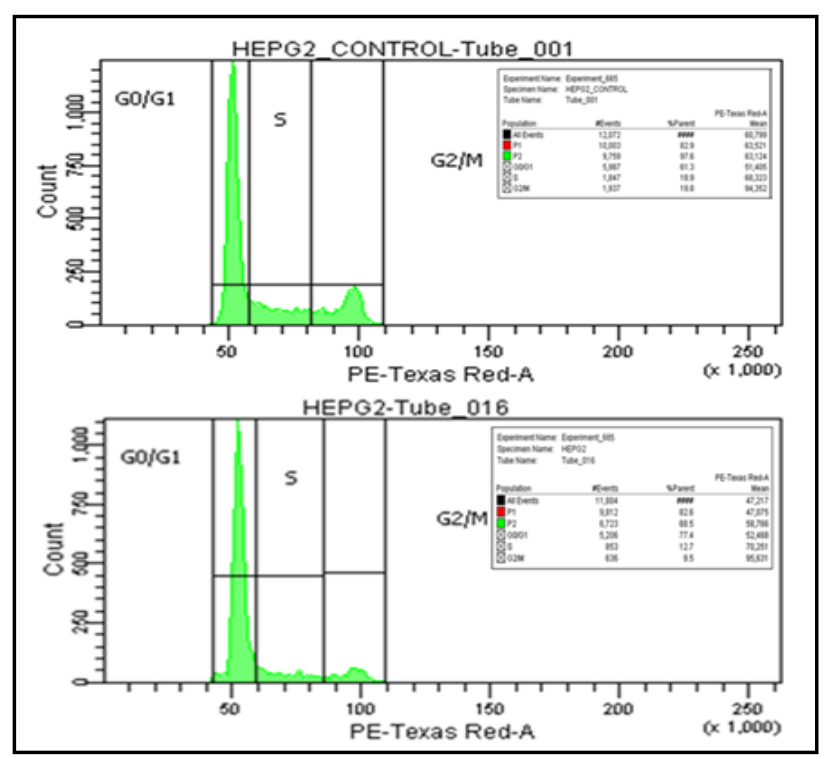

Fig. 9: Flow cytometric analysis of cell cycle phase distribution on Hep-G2 cells in both control and ethyl acetate (ELA at IC 50 doses) fraction of $L$. alba leaves treated cells, respectively after $24 \mathrm{~h}$ treatment. Histograms represented various contents of DNA with the actual number of cells ( $x$-axis denotes the fluorescence intensity of PE-Texas red and $y$-axis denotes count

\section{DISCUSSION}

The discovery of improved cytotoxic agents continues to be an important line in the discovery of modern anticancer drugs. It is not surprising because, in most developed countries and, to an increasing extent in developing countries, cancer is amongst the third most common causes of death and morbidity [20]. The sequel of cancer cells primarily depends on the proliferation control of DNA replication and apoptosis induction through the coordinated cell cycle regulation [21]. After that condensation occurs where reactive oxygen species (ROS) are deleterious to the wound healing process as well as cancer therapy due to the harmful effects on cells and tissues. The antioxidants can interfere with the oxidation process by reacting with free radicals, chelating free catalytic metals and also by acting as oxygen scavengers [15]. Preliminary phytochemical screening, which was carried using chemicals for the identification of various phytoconstituents showed significant presence of tannins, coumarins, carbohydrates, flavonoids, quinone in methanolic extract. Flavonoids and other phenolic compounds from the leaf have been reported as scavengers and inhibitors of lipid peroxidation. High content of flavonoids and phenols in the leaves, generally show stronger antioxidant activity [4]. From the results of total flavonoid content and total poly-phenolic content (table 1) from each fraction of MLA, it was found that ELA fraction had stronger antioxidant activity. The present study is a step towards the exploration of natural antioxidants from MLA extracts of Lawsonia alba Lam. (LA) leaves by the free radical scavenging assays. From the results of DPPH radical scavenging assay, among the three fractions of the MLA extract of LA leaves, ELA fraction was showing potent DPPH scavenging activity. For further confirmation different in vitro methods like hydroxyl radical scavenging assay (table 2) also manifested considerable antioxidant activity of the ELA fraction by increasing the percentage scavenging property with increasing concentrations. Chemoprevention is a novel approach emphasizing on the prevention or delay of carcinogenesis by means of pharmacological, biological, and nutritional intervention and recently, cancer chemoprevention with strategies using foods and medicinal herbs has been regarded as one of the most visible fields for cancer control. The Lawsonia alba Lam. leaves also posses protective effect against liver damage [6]. The present investigation confirmed the apoptosis inducing capacity of Lawsonia alba Lam. leaves on Hep-G2 cells. The anti-proliferative and cytotoxic activities of MLA (fig. 1) and ELA (fig. 2) have been supported by the observations found in MTT assays. ELA inhibited the growth and metabolic activities of Hep-G2 cell line in a concentration and time dependent manner followed by $\mathrm{IC}_{50}$ dose determination. Treatment with ELA on RAW264.7 cells for $24 \mathrm{~h}$ did not show any cytotoxic effect, however it significantly enhanced the cell growth as compared to the control cells (fig. 3). These findings reveal that ELA fraction preferentially acts on Hep-G2 human liver carcinoma cells.

The process of apoptosis is characterized by several morphological changes such as cell shrinkage, membrane blebbing, chromatin condensation, nuclear fragmentation and formation of apoptotic bodies. Light (fig. 4), fluorescence (fig. 5) and confocal microscopic images (fig. 6) clearly showed nuclear disintegration of ELA treated Hep-G2 cells compared to that of the untreated control cells for fluorescence, when stained with acridine orange and ethidium bromide and propidium iodide for confocal microscope study [11] Further evidence in support of the apoptotic activity of ELA was obtained from the gel patterns of agarose gel electrophoresis. ELA treated cells manifested distinct degraded DNA bands like standard (Sorafenib tosylate) in the form of ladders, a typical indication of apoptosis, whereas the untreated control cells showed intact DNA bands when observed in UV transilluminator (fig. 7). Membrane changes leading to PS exposure occur readily in apoptotic cells, while the cell loses membrane integrity later in the apoptotic process and expose DNA [17]. So using a DNA binding dye PI in tandem with flurochrome conjugated Annexin-V, apoptotic cells and necrotic cells can be discriminated by Flow cytometric analysis [22]. The double staining technique showed clear detection of three populations of cells (viable, apoptotic and necrotic). Thus, the early apoptotic cells bind only Annexin-V FITC and late apoptotic cells with both Annexin-V FITC and PI and viable cells do not take any of the dye henceforth, the FSC and SSC is absolutely different for all cell types [23]. Further evidence in support of the apoptotic activity of ELA was obtained from the flow cytometric data analysis (fig. 8). Dual staining with Annexin V FITC and propidium iodide in dot plot assay made it possible to identify live, early apoptosis and late apoptotic cells [24-25]. The increased number of cells in the early and late apoptotic stage after treatment with ELA imply the fact that apoptosis was triggered by the treatment with ELA in Hep-G2 cells. Flow cytometric determination of cell cycle phase distribution has precisely confirmed that ELA causes cell cycle deregulation in HepG2 cell lines. Cell cycle analysis confirmed that treatment with ELA arrested Hep-G2 cell populations in the G0/G1 phase of the cell cycle (fig. 9). To summarize, our results indicate that ethyl acetate fraction of Lawsonia alba Lam. leaves (ELA) possess potent apoptosis inducing capacity on hepatocellular carcinoma cells alongwith free radical scavenging property. Further investigations with the potent fractions are in pipeline to study the mechanistic pathways involved in molecular carcinogenesis. 


\section{ACKNOWLEDGEMENT}

The authors of this paper are very much thankful to Council of Scientific and Industrial Research, Indian Institute of Chemical Biology (CSIR-IICB), Kolkata for providing the funding to perform the research work.

\section{CONFLICT OF INTERESTS}

The authors declare that they have no conflict of interests

\section{REFERENCES}

1. Roopashree R, Mohan CD, Swaroop TR, Jagadish S, Rangappa KS. Synthesis characterization and in vivo biological evaluation of novel benzimidazoles as potential anticancer agents. Asian J Pharm Clin Res 2014;7:309-13.

2. Block TM, Mehta AS, Fimmel CJ, Jordan R. Molecular viral oncology of hepatocellular carcinoma. Oncogene 2003;22:5093-107.

3. Mikhaeil BR, Badria FA, Maatooq GT, Amer MM. Antioxidant and immunomodulatory constituents of henna leave. Z Naturforsch C: Biochem Biophys Biol Virol 2004;59:468-76.

4. Arun P, Purushotham KG, Jayarani JJ, D Kumari V. In vitro antibacterial activity and flavonoid contents of Lawsonia inermis (Henna). Int J PharmTech Res 2010;2:1178-81.

5. Uddin N, Siddiqui BS, Begum S. Chemical constituents and bioactivities of Lawsonia alba Lam. (Henna). J Chem Soc Pak 2013;35:476-85.

6. Bhandarkar M, Khan A. Protective effect of Lawsonia alba Lam. against $\mathrm{CCl}_{4}$ induced hepatic damage in albino rats. Indian J Exp Biol 2003;41:85-7.

7. Babili FE, Valentin A, Chatelain C. Lawsonia inermis: its anatomy and its antimalarial, antioxidant and human breast cancer cells MCF7 activities. Pharm Anal Acta 2013;4:203.

8. Uddin N, Siddiqui BS, Begum S, Bhatti HA, Khan A, Parveen S, et al. Bioactive flavonoids from the leaves of Lawsonia alba (Henna). Phytochem Lett 2011;4:454-8.

9. Kapadia GJ, Rao GS, Sridhar R, Ichiishi E, Takasaki M, Suzuki N, et al. Chemoprevention of skin cancer: effect of Lawsonia inermis L. (Henna) leaf powder and its pigment artifact, lawsone in the epstein-barr virus early antigen activation assay and in two-stage mouse skin carcinogenesis models. Adv Anticancer Agents Med Chem 2013;13:1500-7.

10. Ali NA, Julich WD, Kusnick C, Lindequist U. Screening of yemeni medicinal plants for antibacterial and cytotoxic activities. J Ethnopharmacol 2001;74:173-9.

11. Gupta SD, Debnath A, Saha A, Giri B, Tripathi G, Vedasiromoni $\mathrm{JR}$, et al. Indian black scorpion (Heterometrus bengalensis Koch) venom induced antiproliferative and apoptogenic activity against human leukemic cell lines U937 and K562. Leuk Res 2007;31:817-25.

12. Kokate CK, Purohit AP, Gokhale SB. Pharmacognosy. $42^{\text {nd }}$ ed. Nirali Prakashan; 2008. p. A1-A6.
13. Surveswaran S, Cai YZ, Corke H, Sun M. Systematic evaluation of natural phenolic antioxidants from 133 Indian medicinal plants. Food Chem 2007;102:938-53.

14. Saeed SMG, Sayeed SA, Ashraf S, Naz S, Siddiqi R, Ali R, et al. A new method for the isolation and purification of lawsone from Lawsonia inermis and its ROS inhibitory activity. Pak J Bot 2013;45:1431-6.

15. Narayan S, Mittal A. In vitro antioxidant activity and free radical scavenging potential of roots of red sage. Asian J Pharm Clin Res 2015;8:417-21.

16. Cao Z, Li Y. Chemical induction of cellular antioxidants affords marked protection against oxidative injury in vascular smooth muscle cells. Biochem Biophys Res Commun 2002;292:50-7.

17. Herrmann H, Lorenz HM, Voll R, Grunke M, Woith W, Kalden JR. A rapid and simple method for isolation of apoptotic DNA fragments. Nucleic Acids Res 1994;22:5506-7.

18. Vermes I, Haanen C, Steffens-Nakken H, Reutelingsperger C. A novel assay for apoptosis. Flow cytometric detection of phosphatidylserine expression on early apoptotic cells using fluorescein labeled Annexin V. J Immunol Methods 1995;184:39-51.

19. Jacobson MD, Weil Miguel, Raff MC. Programmed cell death in animal development. Cell 1997;88:347-54.

20. Langman MJ, Cheng KK, Gilman EA, Lancashire RJ. Effect of anti-inflammatory drugs on overall risk of common cancer: a case-control study in general practice research database. $\mathrm{Br}$ Med J 2000;320:1642-6.

21. Lam MH, Liu Q, Elledge SJ, Rosen JM. Chk1 is haploinsufficient for multiple functions critical to tumor suppression. Cancer Cell 2004;6:45-59.

22. Martin SJ, Reutelingsperger CP, Mc Gahon AJ, Rader JA, van Schie RC, La Face DM, et al. Early redistribution of plasma membrane phosphatidylserine is a general feature of apoptosis regardless of the initiating stimulus: inhibition by overexpression of Bcl-2 and Abl. J Exp Med 1995;182:1545-56.

23. Darzynkiewicz Z, Bruno S, Del Bino G, Gorczyca W, Hotz MA, Lassota $\mathrm{P}$, et al. Features of apoptotic cells measured by flow cytometry. Cytometry 1992;13:795-808.

24. Darzynkiewicz Z, Bedner E, Smolewski P. Flow cytometry in analysis of cell cycle and apoptosis. Semin Hematol 2001;38:179-93.

25. Wising C, Azem J, Zetterberg M, Svensson LA, Ahlman K, Lagergard T. Induction of apoptosis/necrosis in various human cell lineages by Haemophilus ducreyi cytolethal distending toxin. Toxicon 2005;45:767-76.

\section{How to cite this article}

- $\quad$ Soumyasree Dutta, Nilanjana Deb, Ashok Kumar Pattnaik, Shila Elizabeth Besra. Apoptosis inducing potential of Lawsonia alba Lam. leaves on hepatocellular carcinoma (HEP-G2) cells along with its anti-oxidant property. Int J Pharm Pharm Sci 2016;8(9):156-162. 